\title{
Holding out for an apology
}

\section{A patient describes how her surgeon's gesture helped her recovery when she experienced complications after surgery}

\section{Anonymous}

My emotional recovery from surgical complications was unbelievably difficult. The anger became haunting, and the physical pain made it impossible to forget the trauma. It was only when I was able to forgive my surgeon that the anger finally lifted - the forgiveness didn't occur in a self righteous way but by accepting that everyone makes mistakes and knowing that my surgeon was sorry for what had happened.

I'd had elective surgery, which went well, but afterwards I experienced complications. I was hit by intense pain, my surgeon came to see me, then went home. I felt that he had left me when I needed him most. He was called back a few hours later to carry out my emergency surgery.

\section{The impression of complacency}

During my recovery in hospital my surgeon didn’t say that he was sorry, and I became angry. I didn't wonder "why me?" I understand that life is a lottery, but the lack of empathy made me think that my surgeon was complacent and indifferent about his patients, and that was why the complications had occurred. I was desperate for him to show that he was sorry.

A few months later, at an outpatient appointment, we discussed further surgery that I needed. The meeting started well, with my surgeon talking about how he had evaluated my case with his colleagues and why he thought the complications had happened. Then he seemed to get defensiveand it felt like the conversation became about him and his reputation, This wasn't helpful because I simply wanted him to reassure me that nothing was more important to him than my recovery, and that he would do whatever he could to help me.

I decided to continue with further surgery. If he was that worried about his reputation then he wouldn't allow anything to go wrong a second time.

\section{A turning point}

What I was looking for came in an unexpected form and at a time when I least expected it. I was on the recovery ward after my corrective surgery and my surgeon came to see me. I pretended to be asleep because I didn't want to talk to him. He held my hand and said that he hoped that I had a better recovery this time. The word sorry was never said, but the sentiment meant a great deal to me. It helped me realise that my surgeon did care about his patients—he just wasn't good at showing it.
That moment was the turning point in my psychological recovery and the anger started to lift.

\section{Understanding that surgeons are human too}

Three years later, although my anger had lifted, I wanted closure. I decided to meet my surgeon to talk about how I wished that when I was in hospital he had sat at my bedside and reassured me that he was there for me, and to tell me that he was sorry for what I was going through. It was therapeutic but extremely difficult to talk about my feelings even after all that time. My surgeon listened patiently and reassured me that he was sorry. He described how doing my corrective surgery had been difficult for him because it brought back memories of the physical trauma he found during my emergency surgery; he recognised how much pain I'd been in. Those insights into his thinking are essential to me. They remind me that my surgeon is only human.

Talking about feelings isn't easy, for patients or for surgeons, but if it helps patients come to terms with what happened then it's worth it. Recovery from surgical complications is much more than just physical.

What you need to know

- Don't get obsessed with fault and blame-what is most important is for patients to know that you care, and that you are there to help them

- Remember that internal anger can cause vulnerable patients to spiral into depression; you have the ability to reduce that risk

- Sorry isn't only expressed in words-gently holding the hand of patients who are vulnerable, or sitting down at their bedside to give support can make all the difference

Education into practice

- What circumstances influence whether you offer an apology, or how you approach it?

- If an operation has not gone well-for example, because of complications, how do you share this with the patient?

- When sharing bad news about an operation, or complication, to what extent do you, or could you, involve other members of the healthcare team?

- Is there anything else that you might think or do differently having read this article?

These questions were developed by the editors and reviewed by the patient author 
Competing interests: I have read and understood BMJ policy on declaration of interests and declare the following: none.

Provenance and peer review: Commissioned, based on an idea from the author: not externally peer reviewed.
Published by the BMJ Publishing Group Limited. For permission to use (where not already granted under a licence) please go to http://group.bmj.com/group/rights-licensing/ permissions 